\title{
Climate change adaptation policy options
}

\author{
Joel B. Smith, Stephanie S. Lenhart \\ Hagler Bailly, Inc., PO Drawer O, Boulder, Colorado 80306-1906, USA
}

\begin{abstract}
Africa is one of the regions of the world potentially most vulnerable to climate change. Warming of the globe due to increased atmospheric concentrations of greenhouse gases appears to be inevitable. Therefore, it is imperative that policy makers in regions such as Africa begin to consider what measures they should take to adapt to the potential conseqences of climate change. A number of adaptation policies are suggested here. The policies address general adaptation measures as well as specific measures in water resources, coastal resources (adapting to sea-level rise), forests, ecosystems, and agriculture. These measures would enhance the flexibility of resources to adapt to climate change and would have net benefits greater than costs. In some cases, the measures make sense without considering climate change because they help address current climate variability. In other cases, the measures must be implemented in anticipation of climate change because they would be ineffective if implemented as a reaction to climate change.
\end{abstract}

KEY WORDS: Climate change $\cdot$ Adaptation $\cdot$ Policy

\section{INTRODUCTION}

The increase in greenhouse gas concentrations in the atmosphere has led many scientists to conclude that the earth's temperature will increase by several degrees over the next century (Houghton et al. 1992, NAS 1992, Wigley \& Raper 1992, Mitchell et al. 1995). Some are beginning to conclude that the anthropogenic effect of increased greenhouse gas concentrations on global climate is already evident (Thomson 1995). To stabilize concentrations of greenhouse gases at current levels, thus reducing the risks of future warming, draconian cuts of 60 to $80 \%$ in anthropogenic emissions of carbon dioxide would be required (Houghton et al. 1990). Given that the Framework Convention on Climate Change seeks only to stabilize emissions from developed countries (UNEP/ WMO 1992), it appears likely that atmospheric concentrations of greenhouse gases will continue to rise. If they do, warming of the climate is highly likely.

If climate change is inevitable, then it is probably inevitable that the sea level will rise, agricultural pro- duction will change, runoff and water supply will change, and the location of forests and other terrestrial vegetation will shift poleward and to higher altitudes (Tegart et al. 1990, Smith et al. 1995). Society will have to adapt to these and other changes.

Africa may be particularly vulnerable to climate change. For example, African countries tend to have a much higher share of their economy in climate-sensitive sectors. Most African countries have at least one-third to one-half of their GNP in agriculture (World Bank 1992). Major cities such as Lagos, Nigeria, with a population of 8 million people and Alexandria, Egypt, with a population of 3 million are vulnerable to sea-level rise (El-Raey et al. 1995, French et al. 1995). River basins such as the Nile and Zambezi are critical sources of water for irrigation and hydropower and their flows are quite sensitive to climate variability (and hence, change) (Gleick 1993). Africa has more projects to protect biodiversity than other major areas of the world (World Resources Institute 1994). These projects could be threatened by climate change (Smith et al. 1995). Thus, it is important 
for Africans to consider how they will adapt to climate change.

There are 2 fundamental types of adaptation: reactive and anticipatory (Smith in press). Reactive adaptations are measures taken as a response to climate change. For example, a farmer may notice that droughts are becoming more persistent and may switch to more drought tolerant varieties of crops. Anticipatory adaptations are measures taken in advance of climate change. These are taken to minimize or offet the effects of climate change.

One of the first steps in responding to climate change is to identify the policy options available to address the adverse effects of such change. This article describes a number of government policies that could be implemented in anticipation of climate change to reduce its potential adverse effects. The policy options are divided into 5 climate-sensitive sectors: water resources, coastal resources (sea-level rise), forests, ecosystems, and agriculture. The 5 lists of anticipatory adaptation options presented here represent the range and type of policies that should be considered; however, the lists are not comprehensive. These lists are meant to provide policy makers with ideas about possible adaptation measures and to stimulate the identification of other adaptation measures.

\section{CRITERIA FOR ANTICIPATORY ADAPTATION OPTIONS AND ORGANIZATION OF POLICY LISTS}

All anticipatory adaptation policies should satisfy at least 2 criteria: flexibility and the potential for benefits to exceed costs. The regional impacts of climate change are highly uncertain. For example, Strzepek et al. (1995) found that under some scenarios, the flow of the Nile River could increase by $30 \%$, while under other scenarios, the flow could be reduced by more than half. If adaptation measures only addressed one type of climate change, such as increased flooding due to wetter conditions, they might leave the sector vulnerable to another type of climate change, such as drought from drier conditions. To address the broad range of uncertainties, anticipatory adaptation policies should be flexible. The objective in selecting an anticipatory adaptation policy should be to enhance the ability to meet stated objectives under a wide range of climatic conditions. As such, a policy may be either robust, meaning it allows the system to continue functioning under a wider range of conditions; or resilient, meaning it allows the system to quickly adapt to changed conditions.

The notion of benefits exceeding costs (i.e. net benefits greater than zero, referred to hereafter as 'net benefits') is a sensible one for public policies. It has a par- ticular implication for adaptation policies. Mitchell et al. (1995) estimate that the most likely rate of average global warming is approximately $0.2^{\circ} \mathrm{C}$ per decade, a rate at which significant effects of climate change may not be realized for many decades. Similarly, the benefits of anticipatory adaptation policies also may not be realized for many decades. If discounting is used, the net present value of the benefits of anticipating climate change may be low. Thus, only minimal expenditures for adapting to climate change, such as marginal changes in infrastructure and changes in planning, may be economically justified.

In addition to being flexible and having the potential for benefits to be greater than costs, anticipatory adaptation options that meet the following criteria should be implemented now to address climate change.

- Net benefits independent of climate change. Some adaptation options may yield net benefits even if climate change does not occur. Many of these options involve changing plans for responding to particular climate events such as floods or droughts or allowing greater flexibility in response to current climate variability. For example, implementing market based systems for allocating water would result in more efficient allocation of water under the current climate and would allow for a more rapid and efficient response to climate change than would more rigid schemes for water allocation (Frederick \& Kneese 1990).

- High priority. Some adaptation options need to be implemented in anticipation of climate change because they would be significantly less or not effective if implemented as reactive policies. Adaptation options that fall into the following sub-categories may be considered high priority:

- Irreversible or catastrophic impacts. These options are policies concerning potentially irreversible or catastrophic impacts of climate change; for example, loss of life or of species, extensive loss of property, or destruction of resources may be irreversible or catastrophic. Such policies warrant consideration because reactive measures will probably be unsuccessful in mitigating the impacts of climate change.

- Long-term decisions. Decisions on many long-term issues, such as the construction of dams, reservoirs,

\footnotetext{
${ }^{1}$ If the policy will not produce benefits for many decades, the costs of implementation may need to be quite small in comparison with undiscounted future benefits. Suppose an adaptation policy reduces the damages from a catastrophic flood by $\$ 1$ billion in the year 2075 . The benefit in the year 2075 is $\$ 1$ billion. Let us assume that it costs $\$ 100$ million to adopt the policy. At a $3 \%$ discount rate, the present value (in 1994) of the $\$ 1$ billion in damages is $\$ 91.2$ million. Therefore, the net present value of the benefits of this policy are lower than the costs and, from an economic viewpoint, the investment is not justified
} 
and bridges, have long useful lifetimes and may be affected by climate change. Policies affecting the construction of such structures warrant consideration because the initial costs of making the structures less vulnerable to climate change are likely to be significantly less than the costs of adapting the structures after climate changes (NAS 1992).

- Unfavorable trends. Certain trends in growth or resource use may make some types of adaptation more difficult; for example, the fragmentation of habitats is a trend that is unfavorable to wildlife. As climate changes, fragmentation could become an even greater problem as species need to migrate to cooler areas. Policies affecting such trends warrant consideration before climate change, because adaptation may be more difficult in the future or because opportunities to implement low-cost or politically feasible options may be lost (Smith in press).

The following sections of this article list anticipatory adaptation options that increase flexibility and have benefits greater than costs. Each individual anticipatory adaptation option is described and we indicate whether the option has net benefits independent of climate change or is of high priority. If the option is of high priority, we indicate whether it is high priority because it has irreversible or catastrophic impacts, is a long-term decision, or has unfavorable trends. All of the options listed below meet the general criteria of being flexible and having the potential for a favorable benefit-cost analysis. Where appropriate, we have cited examples of implementing these policies in Africa.

This article covers the following topics

- general policy options for adaptation to climate change,

- policy options for adaptation of water resources,

- policy options for adaptation to a rise in sea level,

- policy options for adaptation of forests,

- policy options for adaptation of ecosystems, and

- policy options for adaptation of agriculture.

This list of anticipatory adaptation options is meant to be useful to all regions of the world. Whether and how these policies are applied in specific regions and countries depends on local circumstances and such matters as whether it is institutionally, culturally, or socially feasible to implement these changes. Thus, the nature of actual adaptation measures may be different in Africa than in other areas.

\section{GENERAL POLICY OPTIONS FOR ADAPTATION TO CLIMATE CHANGE}

The measures in this category can be thought of as broad strategies rather than specific policies. They may be used to complement specific policies addressing problems within a vulnerability sector, such as the examples provided in the policy option lists for each sector.

Incorporate climate change in long-term planning. Long-term planning for climate-sensitive resources should incorporate changes in conditions that will affect the services provided by those resources. Changes in population and income will affect resource use. So will climate change. Including climate change in long-term plans could result in changes being made that will enhance the ability of future generations to cope with these changes. For example the government of Malawi is identifying possible modifications to projects planned for implementing the National Environmental Action Plan and the National Disaster Action Plan to ensure that climate change considerations are included (Theu et al. in press).

This option is high priority because of irreversible or catastrophic impacts.

Inventory existing practices and decisions used to adapt to different climates. An inventory may focus on actual social and economic decisions in light of variable climatic regimes over time or across regions. For example, agricultural practices in arid and semiarid areas in Africa, such as the Sahel, could be used in areas that may become drier due to climate change. Compilation of information on various practices may be a cost-effective way to identify feasible options for adaptation. In particular, adaptation options that require long-term decisions should be identified and analyzed for implementation (Johda 1989, IPCC 1990; additional research recommendations in Canadian Climate Program 1993, OTA 1993a, b).

This option is high priority because of long-term decisions, irreversible or catastrophic impacts, and unfavorable trends.

Tie disaster relief to hazard-reduction programs. Funds for disaster relief could be tied to the implementation of long-term hazard-reduction policies. Such requirements may be a valuable investment, particularly if hurricanes and storms increase as a result of climate change (OTA 1993a). This policy would likely have net benefits under current climate because current risks from disasters would be reduced.

This option receives high priority because of irreversible or catastrophic impacts and long-term decisions. Net benefits are independent of climate change

Promote awareness of climatic variability and change. Climatic variability and the potential risks of climate change are often not well understood by the public or by decision makers. Because climatic adaptation will affect the individual, organizational, and pol- 
icy levels, communication about the human significance of climatic variability is important at all levels in a community. Increasing sensitivity to climatic issues will facilitate adoption of measures to prepare for climatic variability and change (Johda 1989, IPCC 1990, Cooper 1992).

This option is high priority because of irreversible or catastrophic impacts, long-term decisions, and unfavorable trends. Net benefits are independent of climate change.

\section{POLICY OPTIONS FOR ADAPTATION OF WATER RESOURCES}

Use river basin planning and coordination. Comprehensive planning across a river basin may allow coordinated solutions to problems of water quality and water supply; for example, enhanced coordination of facility system operations or expansion of the conjunctive use of groundwater and surface water can improve water yields, which can help to alleviate droughts. Planning can also help to address the effects of population, economic growth, and changes in the supply of and demand for water (Gillilan 1992, Schad 1992, Wahl 1992, Warren 1992). For example, Strzepek et al. (1995) found that Egypt and Sudan will need to improve their coordination and planning of allocation of Nile River water to anticipate climate change.

This option receives high-priority consideration because of irreversible or catastrophic impacts and unfavorable trends. Net benefits are independent of climate change.

Adopt contingency planning for drought. Plans for short-term measures to adapt to water shortages could help mitigate droughts. Planning could be undertaken for droughts of known or greater intensity and duration. The cost of developing contingency plans is relatively small compared with the potential benefits. Additionally, plans could be effective in managing current climatic variability, as well as future climate change (Wilhite 1990, Cooper 1992, NAS 1992, Wahl 1992).

This option receives high-priority consideration because of irreversible or catastrophic impacts. Net benefits are independent of climate change.

Make marginal changes in construction of infrastructure. Marginal changes may be made in the planned construction of water resources infrastructure such as reservoirs and flood control works to adapt to increased variability in runoff or to a need for greater storage capacity. In planned construction, marginal increases in the size of dams or marginal changes in the construction of canals, pipelines, pumping plants, and storm drainages should be considered. This change may be much less expensive than adding capacity in the future (NAS 1992, Canadian Climate Program 1993).

This option receives high-priority consideration because of long-term decisions.

Use interbasin transfers. Transfers of water between water basins may result in more efficient water use under current and changed climate. Transfers are of ten easier to implement than fully operating markets for water allocation. Transfers also can be an effective short-term measure for responding to regional droughts or other problems of water supply (Wahl 1992. Canadian Climate Program 1993).

Net benefits are independent of climate change.

Maintain options to develop new dam sites. Keep options open to develop new dam sites, should they be needed. The number of sites that can be used efficiently as reservoirs is limited, and removing structures once an area has been developed may be very costly or politically difficult. Thus, development in potential dam sites should be limited or only allowed under terms that would permit conversion to dam sites (e.g. leases) (Smith \& Tirpak 1989)

This option receives high-priority consideration because of unfavorable trends.

Conserve water. Reducing demand can increase excess supply, creating a greater margin of safety for future droughts. Demand for water may be reduced through a range of policies that encourage efficient water use including education, voluntary compliance, pricing policies, legal restrictions on water use, rationing of water, or the imposition of water conservation standards on technologies. Reduced demand will increase current capacity to cope with drought (Canadian Climate Program 1993, OTA 1993a)

Net benefits are independent of climate change.

Allocate water supplies by using market-based systems. Market-based allocation allows water to be diverted to its most efficient uses. Other mechanisms, such as prior appropriation, may result in inefficient allocation of water supplies. Market-based allocations are able to respond more rapidly to changing conditions of supply and also tend to lower demand, thus conserving water. Consequently, market-based allocation increases both the robustness and the resiliency of the water supply system. In addition, it will improve the economic efficiency of the allocation system under the current climate (Frederick \& Gleick 1989, Wahl 1992)

Net benefits are independent of climate change.

Control pollution. Polluting water so that it is unfit for drinking or other uses can, in many respects, have an effect similar to reducing water supply. Reducing water pollution effectively increases the supply of 
water. In turn, a larger water supply increases the safety margin for maintaining water supplies during droughts. In addition, reduced runoff from climate change will most likely increase concentrations of pollutants in the water column. If pollutant loadings are lower, water quality standards are less likely to be violated. These benefits will be realized whether or not climate changes (Schad 1992, Canadian Climate Program 1993).

Net benefits are independent of climate change.

\section{POLICY OPTIONS FOR ADAPTATION TO SEA LEVEL RISE}

Plan urban growth. Redirecting growth away from sensitive lands and toward less vulnerable areas is one option to reduce the risks associated with a sea-level rise, and also to reduce vulnerability to severe coastal storms that happen under current climate conditions. This option may be particularly useful in decisions to site large capital facilities or facilities that would pose significant hazards if subject to flooding (Wang et al. 1995).

This option receives high-priority consideration because of unfavorable trends. Net benefits are independent of climate change.

Decrease subsidies to develop sensitive coastal lands. Limit government subsidies or tax incentives to develop land sensitive to sea-level rise, such as barrier islands, coastal wetlands, estuarine shorelines, and critical wildlife habitat. Such policies would include ensuring that any government subsidies for flood insurance reflect the current risks of developing in coastal areas and on floodplains and would possibly include prohibiting new insurance policies in risky locations. Additionally, insurance and banking industries may be encouraged to factor risks of climatic variability into investment decisions and thereby reduce reliance on government-subsidized insurance and disaster relief. Such policies would allow markets to reflect the true risks of developing or living in sensitive coastal areas (Warren 1992, Canadian Climate Program 1993, OTA 1993a).

This option receives high-priority consideration because of unfavorable trends. Net benefits are independent of climate change.

Use set-backs for coastal development. Set-backs for coastal development buy some time to avoid the destructive effects of sea-level rise. The buffer zones enable sea level to rise up to a point without threatening coastal development. Beyond that point, response measures will need to be taken. For example, French et al. (1995) recommended incorporating buffer zones between the shore and new coastal development in Nigeria.

This option receives high-priority consideration because of unfavorable trends.

Discourage permanent shoreline stabilization. Permanent shore-hardening structures, such as seawalls and groins, may be banned or discouraged in moderately developed areas. Limiting permanent stabilization of the shoreline will allow a gradual retreat from a sea-level rise and will allow the development market to determine if a property is worth developing, given the risk of erosion or inundation. However, well-developed coastal communities and expensive facilities may represent such a large investment that expansion of coastal barriers to protect the investments from a sea-level rise is warranted (OTA 1993a).

This option receives high-priority consideration because of unfavorable trends and long-term decisions.

Incorporate marginal increases in the height of coastal infrastructure.

In building coastal infrastructure, such as bridges or seawalls, marginal increases in the height of the structures may be included to offset a sea-level rise. For example, outflow from sewage treatment plants could be several feet higher to offset a sea-level rise. Such additions are less expensive to make while construction is in progress than after the initial work is complete (NAS 1992).

This option is high priority because of long-term decisions.

Preserve vulnerable coastal wetlands. Efforts should be made to maintain coastal wetlands that are more likely to withstand a sea-level rise. Wetlands are valuable natural areas that are difficult to re-create; therefore, current and future efforts are warranted to protect the areas. In setting priorities for protecting wetlands, the likelihood of surviving a sea-level rise or migrating landward should be considered. Protecting wetlands will also improve water quality, flood control and fish and wildlife habitat under current climate conditions (Warren 1992, Canadian Climate Program 1993).

This option receives high-priority consideration because of irreversible or catastrophic impacts. Net benefits are independent of climate change.

\section{POLICY OPTIONS FOR ADAPTATION OF FORESTS}

Enhance forest seed banks. Maintaining access to a sufficient variety of seeds to allow the original genetic diversity of forests to be rebred provides an assurance that the benefits provided by forests are 
not lost forever. Seed collections should represent the variety of genotypes that exist for each species (OTA $1993 \mathrm{~b})$

This option receives high-priority consideration because of irreversible or catastrophic impacts.

Encourage diverse management practices. A mix of forest management practices, strategies, and species may provide a buffer against the uncertainties of climate change. Diverse practices include a mix of planting practices, a greater variety of species, planting of species drawn from warmer climate zones, and an increase in planting densities. One example of how this policy has been implemented is the planting of trees with greater resistance to heat and drought on the southern range of managed forest boundaries if the trees can survive in the current climate. In addition, a mix of different timber-harvesting strategies may be used to promote forest diversity (Smith 1992, OTA $1993 \mathrm{~b}$ ).

This option receives high-priority consideration because of long-term decisions.

Establish flexible criteria for intervention. Policies should be in place that establish flexible criteria for the use of existing forest intervention management practices. The use of management practices such as salvage harvests, silvicultural management, insect and fire control, and restoration activities should be allowed to change as conditions change. Such policies apply to current forest management but should also consider how the structure of the forest might change because of climate change (Cooper 1992, Smith 1992).

This option receives high-priority consideration because of irreversible or catastrophic impacts. Net benefits are independent of climate change.

Reduce habitat fragmentation and promote development of migration corridors. Geographic fragmentation may threaten the ability of forests and forest species to migrate or adapt to changing climate. Currently, the health of many forests is stressed by existing fragmentation. This stress will most likely increase under climate change. Forest fragmentation may be reduced through incentive programs for multiple-use management that balances preservation and use within a single parcel or through the negotiation of conservation easements that protect geographically important land parcels from development. Such programs should consider the likelihood that climate change will cause forests to migrate in a poleward or vertical direction. Also note that the rate of forest migration may lag far behind the rate of climate change (OTA 1993b).

This option receives high-priority consideration because of irreversible or catastrophic impacts and unfavorable trends. Net benefits are independent of climate change.

\section{POLICY OPTIONS FOR ADAPTATION OF ECOSYSTEMS}

Integrated ecosystem planning and management. Integrated planning and management along watershed and ecosystem lines reduce the institutional fragmentation in the management of natural areas and focus on protecting a variety of species and natural systems. Because the impacts of climate change are difficult to predict, the preservation of a variety of species in a healthy ecosystem may be the most effective way to protect those species that will be able to adapt to climate change. In many cases, this preservation will involve international coordination. Such coordination will most likely produce net benefits even if climate does not change because coordination will help to address many of the threats to the diversity of species (Cooper 1992, Warren 1992, OTA 1993b).

This option receives high-priority consideration because of irreversible or catastrophic impacts. Net benefits are independent of climate change.

Protect and enhance migration corridors or buffer zones. Policies that protect migration corridors or buffer zones help maintain ecosystems by improving the likelihood of successful adaptation to climate change by animal and plant species. Corridors, where they can be identified, allow species to migrate as climate changes. Buffer zones around current reserve areas that include different altitudes and ecosystems increase the adaptive potential for species within the preserve. A graded system of management may be implemented, where the innermost areas receive the greatest protection and where more uses are allowed in the outer buffer zones or corridors. Diverse natural lands and larger land parcels will improve the possibility of species adaptation to climatic variability. Note that the current lack of information on species migration, natural barriers to migration, and the high level of development surrounding many natural areas significantly limit the feasibility of this option (NAS 1992, Lillieholm 1993, OTA 1993b).

This option receives high-priority consideration because of irreversible or catastrophic impacts and unfavorable trends. Net benefits are independent of climate change.

Enhance methods to protect biodiversity off-site. Threatened or endangered species may be saved offsite, which protects diversity. These methods must be in place before climate changes to avoid the irreversible loss of species extinction. Off-site methods to assist adaptation include gene and seed banks, libraries, gardens, and zoos. Off-site protection may be very important in preventing irreversible loss of biodiversity (NAS 1992).

This option receives high-priority consideration because of irreversible or catastrophic impacts. 


\section{POLICY OPTIONS FOR ADAPTATION OF AGRICULTURE}

Develop new crop types and enhance seed banks. Seed banks that maintain a variety of seed types provide an opportunity for farmers to diversify, allowing them to both counter the threat of climate change and develop a profitable specialization. Development of more and better heat-and drought-resistant crops will help fulfill current and future world food demand by enabling production in marginal areas to expand. Improvements will be critical because the world population continues to increase, with or without climate change (NAS 1992, OTA 1993a).

This option receives high-priority consideration because of irreversible or catastrophic impacts. Net benefits are independent of climate change.

Avoid monoculture and encourage farmers to plant a variety of heat- and drought-resistant crops. Growing of single crops such as maize increases farmers' vulnerability to climate variability. If the probability of droughts and heat waves increases with climate change, such vulnerability can increase. One adaptation option is for farmers to plant a wider variety of crops to reduce the risks of crop failure. Through its agricultural extension service, the government of Malawi has been advising farmers to grow droughtresistant food crops such as cassava, millet, sorghum, etc. (Theu et al. in press).

Net benefits are independent of climate change.

Avoid tying subsidies or taxes to type of crop and acreage. Commodity support programs or tax policies may discourage switching from one cropping system to another that is better suited to a changed climate. Therefore, efforts to stabilize farm supply and to maintain farm incomes should avoid disincentives for farmers to switch crops, rotate crops, and use the full acreage normally planted. This policy approach will increase the efficiency of current farming practices and will also increase the ability of the system to quickly recover from climate change (Lewandrowski \& Brazee 1993).

Net benefits are independent of climate change.

Increase efficiency of irrigation. Many farming technologies, such as efficient irrigation systems, provide opportunities to reduce direct dependence on natural factors such as precipitation and runoff. In evaluating an improvement to irrigation systems, the additional benefit of reducing vulnerability to climatic variations and natural disasters should be considered. Improvements allow greater flexibility by reducing water consumption without reducing crop yields. This will also help in adapting water resources.

Net benefits are independent of climate change.
Disperse information on conservation management practices. Many practices, such as conservation tillage, furrow diking, terracing, contouring, and planting vegetation to act as windbreaks, will protect fields from water and wind erosion and can help retain moisture by reducing evaporation and increasing water infiltration. Using management practices that reduce dependence on irrigation will reduce water consumption without reducing crop yields and will allow greater resiliency in adapting to future climate changes (Easterling 1993).

Net benefits are independent of climate change.

Liberalize agricultural trade. Lowering trade barriers will result in higher levels of global agricultural production both under the current climate and under climate change scenarios. Farmers will receive information on changes in global market conditions faster than if trade barriers were not lowered (Rosenzweig \& Parry 1994).

Net benefits are independent of climate change.

Promote agricultural drought management. Encourage management practices that recognize drought as part of a highly variable climate, rather than treating drought as a natural disaster. Farmers can be given information on climatic conditions, incentives can be offered to adopt sound practices of drought management, and farmers can be discouraged from relying on drought relief. This type of policy is particularly useful if farm disaster relief and other government subsidies distort the market and encourage overly risky expansion of farming into marginal lands (OTA 1993a).

Net benefits are independent of climate change.

\section{CONCLUSION}

The policy options described above are among many that could reduce the potential risks of climate change for Africa and the rest of the world. The policies are summarized in Table 1. This is not meant to be an exhaustive list, but one that is suggestive of what can be done to prepare for climate change. Policy makers in Africa should evaluate these options based on the degree to which they may help address known climate variability and other current concerns as well as the degree to which they will ease potential burdens on future generations. The easiest political course for decision makers may be to ignore climate change until its effects are felt. This, however, will leave it entirely up to future generations to bear the full costs of adapting to our legacy of increased greenhouse gas concentrations. It is interesting that countries such as Malawi are beginning to address climate change in their longterm planning (Theu et al. in press). Making incremental changes now will make it easier for future generations to cope with climate change. 
Table 1. Summary of adaptation policy options

\begin{tabular}{|c|c|c|}
\hline Policies & $\begin{array}{l}\text { Net benefits independent } \\
\text { of climate change }\end{array}$ & High priority \\
\hline \multicolumn{3}{|l|}{ General policies } \\
\hline Incorporate climate change in long-term planning & & $\checkmark$ \\
\hline Inventory existing practices & & $\checkmark$ \\
\hline Tie disaster relief to hazard-reduction programs & $\checkmark$ & $\checkmark$ \\
\hline Promote awareness & $\checkmark$ & $\checkmark$ \\
\hline \multicolumn{3}{|l|}{ Water resources } \\
\hline River basin planning and coordination & $\checkmark$ & $\checkmark$ \\
\hline Contingency planning for drought & $\checkmark$ & $\checkmark$ \\
\hline Marginal changes in construction of infrastructure & & $\checkmark$ \\
\hline Use interbasin transfers & $\checkmark$ & \\
\hline Options for new dam sites & & $\checkmark$ \\
\hline Conserve water & $\checkmark$ & \\
\hline Use markets to allocate supplies & $\checkmark$ & \\
\hline Control pollution & $\checkmark$ & \\
\hline \multicolumn{3}{|l|}{ Sea-level rise } \\
\hline Plan urban growth & $\checkmark$ & $\checkmark$ \\
\hline Decrease subsidies to sensitive lands & $\checkmark$ & $\checkmark$ \\
\hline Set-backs & & $\checkmark$ \\
\hline Discourage permanent shoreline stabilization & & $\checkmark$ \\
\hline Marginal increases in the height of coastal infrastructure & & $\checkmark$ \\
\hline Preserve vulnerable wetlands & $\checkmark$ & $\checkmark$ \\
\hline \multicolumn{3}{|l|}{ Forests } \\
\hline Forest seed banks & $\checkmark$ & $\checkmark$ \\
\hline Diverse management practices & & $\checkmark$ \\
\hline Flexible criteria for intervention & $\checkmark$ & $\checkmark$ \\
\hline Reduce habitat fragmentation; develop migration corridors & $\checkmark$ & $\checkmark$ \\
\hline \multicolumn{3}{|l|}{ Ecosystems } \\
\hline Integrated ecosystem planning and management & $\checkmark$ & $\checkmark$ \\
\hline Migration corridors or buffer zones & $\checkmark$ & $\checkmark$ \\
\hline Protect biodiversity off-site & & $\checkmark$ \\
\hline \multicolumn{3}{|l|}{ Agriculture } \\
\hline New crops and seed banks & $\checkmark$ & $\checkmark$ \\
\hline Plant a variety of heat- and drought-resistant crops & $\checkmark$ & \\
\hline Avoid production subsidies & $\checkmark$ & \\
\hline Increase irrigation efficiency & $\checkmark$ & \\
\hline Conservation management & $\checkmark$ & \\
\hline Liberalize agricultural trade & $\checkmark$ & \\
\hline Drought management & $\checkmark$ & \\
\hline
\end{tabular}

\section{LITERATURE CITED}

Canadian Climate Program (1993) Adaptation to climatic variability and change, task force report on climate adaptation. Occasional paper 19. University of Guelph, Ontario, Canada

Cooper CF (1992) Sensitivities of western United States ecosystems to climate change. Contractor report. Prepared for the Office of Technology Assessment, Washington, DC

Easterling WE (1993) Adapting United States agriculture to climate change. In: Preparing for an uncertain climate, Vol 1, OTA-O-567 Office of Technology Assessment, Washington, DC, p 303-305

El-Raey M, Sasr S, Frihy O, Desouki S, Dewidar Kh (1995) Potential impacts of accelerated sea level rise on Alexandria governate, Egypt. J Coast Res, Spec Issue 14:190-204

Frederick KD, Gleick PH (1989) Water resources and climate change. In: Rosenberg $N$ et al. (eds) Greenhouse warming: abatement and adaptation. Resources for the Future, Washington, DC, p 133-146

Frederick KD, Kneese AV (1990) Reallocation by markets and prices. In: Waggoner PO (ed) Climate change and United States water resources. John Wiley \& Sons, New York, p 395-419

French GT, Awosika LF, Ibe CE (1995) Sea level rise and Nigeria: potential impacts and consequences. J Coast Res, Spec Issue 14:224-242

Gillilan D (1992) Innovative approaches to water resource management. Contractor report. Prepared by the University of Arizona, Tucson, for the Office of Technology Assessment, Washington, DC

Gleick P (ed) (1993) Water in crisis. Oxford University Press, New York

Houghton JT, Callander BA, Varney SK (1992) Climate change 1992 - the supplementary report to the IPCC scientific assessment. WMO/UNEP intergovernmental panel on climate change. Cambridge University Press, Cambridge 
Houghton JT, Jenkins GJ, Ephraums JJ (eds) (1990) Climate change: the IPCC scientific assessment. Cambridge University Press, New York

IPCC (Intergovernmental Panel on Climate Change) (1990) Policy makers summary of the formulation of response strategies: Report of working group III, WMO/UNEP intergovernmental panel on climate change. IPCC, Geneva

Johda NS (1989) Potential strategies for adapting to greenhouse warming: perspectives from the developing world. In: Rosenberg $N$ et al. (eds) Greenhouse warming: abatement and adaptation. Resources for the Future Washington, DC, p 147-158

Lewandrowski JK, Brazee RJ (1993) Farm programs and climate change. Clim Change 23:1-20

Lillieholm RJ (1993) Preserves at risk: an investigation of resource management strategies, implications and opportunities. In: Preparing for an uncertain climate, Vol 2, OTA-O-567. Office of Technology Assessment, Washington, DC, p 244-250

Mitchell JFB, Johns TC, Gregory JM, Tett SFB (1995) Climate response to increasing levels of greenhouse gases and sulphate aerosols. Nature 376:501-504

NAS (National Academy of Sciences) (1992) Policy implications of greenhouse warming. National Academy Press, Washington, DC

OTA (Office of Technology Assessment) (1993a) Preparing for an uncertain climate, Vol 1, OTA-O-567 Office of Technology Assessment, Washington, DC

OTA (Office of Technology Assessment) (1993b) Preparing for an uncertain climate, Vol 2, OTA-O-568. Office of Technology Assessment, Washington, DC

Rosenzweig C, Parry ML (1994) Potential impact of climate change on world food supply. Nature 367: 133-138

Schad TM (1992) A new commission to study United States water policy. Draft report (contract 13-5820.0). Prepared for the Office of Technology Assessment, Washington, DC

Smith JB (in press) Setting priorities for adapting to climate change. Environ Prof

Smith JB, Strzepek KM, Kalkstein LS, Nicholls RJ, Smith TM, Riebsame WE, Rosenzweig C (1995) Executive summary. In: Strzepek KM, Smith JB (eds) As climate changes: international impacts and implications. Cambridge University Press, Cambridge, p 4

Smith JB, Tirpak DA (eds) (1989) The potential effects of global climate change on the United States. EPA-230-0589-050. US Environmental Protection Agency, Washington, DC
Smith W (1992) Managing forests under a changing climate workshop summary. Presented at a workshop convened by the Office of Technology Assessment. June 18-19, 1992. Washington, DC

Strzepek KM, Onyegi SC, Saleh M, Yates D (1995) An assessment of integrated climate change impacts on Egypt. In: Strzepek KM, Smith JB (eds) As climate changes: international impacts and implications. Cambridge University Press, Cambridge

Tegart WJ, Sheldon McG, Griffiths DC (1990) Climate change - the IPCC impacts assessment. WMO/UNEP intergovernmental panel on climate change. Australian Government Publishing Service, Canberra

Theu J, Chavula G, Elias C (in press) Malawi: how climate change adaptation options fit within the FCCC national communication and national development plans. In: Smith JB, Bhatti N, Menzhulin G, Campos M, Benioff R, Rijsberman $F$, Jallow $B$ (eds) Adapting to climate change: assessments and issues. Springer Verlag, New York

Thomson DJ (1995) The seasons, global temperature, and precession. Science 268:59-68

UNEP/WMO (United Nations Environment Programme/ World Meteorological Organization) (1992) United Nations Framework Convention on Climate Change. Climate Change Secretariat, Geneva

Wahl R (1992) The management of water resources in the western United States and potential climate change. Contractor report. Prepared by the University of Colorado, Boulder, for the Office of Technology Assessment, Washington, DC

Wang B, Chen S, Zhang K, Shen J (1995) Potential impacts of sea level rise on the Shanghai area. J Coast Res Spec Issue $14: 151-166$

Warren RS (1992) Coastal land vulnerabilities to climate change. Contractor report. Prepared for the Office of Technology Assessment, Washington, DC

Wigley TML, Raper SCB (1992) Implications for climate and sea level of revised IPCC emissions scenarios. Nature 357 : 293-324

Wilhite DA (1990) Planning for drought: a process for state government. IDIC technical series 90-1 International Drought Information Center, University of Nebraska, Lincoln

World Bank (1992) World development report 1992. Oxford University Press, New York

World Resources Institute (1994) World resources 1994-95. Oxford University Press, New York 